\title{
Identifying the Virtuous Circle of Humanity Education and Post-Graduate Employment: Evidence from a Confucian Country
}

\author{
Wonyoung Baek ${ }^{1}$ and Joonmo Cho ${ }^{2, *}$ \\ 1 HRD Center, Sungkyunkwan University, 25-2, Sungkyunkwan-ro, Jongno-gu, Seoul 03063, Korea; \\ bwy86@hanmail.net \\ 2 College of Economics, Sungkyunkwan University, 25-2, Sungkyunkwan-ro, Jongno-gu, Seoul 03063, Korea \\ * Correspondence: trustcho@skku.edu; Tel.: +82-2-760-0422
}

Received: 28 November 2017; Accepted: 12 January 2018; Published: 15 January 2018

\begin{abstract}
As education for sustainable development receives continuing attention, universities provide regular courses, education programs, and individual activities on human rights, diversity, and corporate responsibilities. This study conducts an empirical analysis of a virtuous circle between experience in extracurricular programs as part of humanity education and performance in the labor market based on Education-Career matched data of 15,180 students who graduated from one of the Confucian-based universities between 2008 and 2015. The analysis found that employment is positively affected by not only grades but also extracurricular activities related to humanities, such as completion of an education and practice course on etiquette and social service activities. These findings are significant in verifying that the level of refinement of university students and their participation in social volunteering can have positive effects on employment, thereby leading to the sustainability of a virtuous circle between education and social and economic activities. Therefore, universities should formulate an educational system that integrates expertise, human growth, equality, and human rights, and firms should establish a specific employment manual to identify the invisible characteristics of job seekers to facilitate the sustainability of a virtuous circle between education and social and economic activities.
\end{abstract}

Keywords: sustainable development; university education; confucianism; humanity education; post-graduate employment

\section{Introduction}

The concepts of sustainable development and teaching and learning for sustainability have been widely discussed since they were mentioned at the World Commission on Environment and Development in 1987 and the UN Conference on Environment and Development in Rio de Janeiro in 1992 [1]. Sustainability is currently treated as more significant in higher education at the global level [2], and as universities begin to consider sustainability as a core value in education, there is a need to contemplate the role of transformative learning in higher education [3]. The basic responsibility of higher education in sustainability includes education for next-generation global citizens focusing on their roles as social leaders and an attitude of respect and dedication to society and care for others [4-6].

Many students in Korean universities tend to study for extended entrance examinations. In other words, they are studying to obtain a good job just as they studied to attend a good university. However, it is becoming increasingly necessary to systematically provide humanities education to college students to enable harmonious development of students' abilities, which at present faces many challenges due to the rapid changes in society and an educational system centered on entrance examinations in Korea $[7,8]$. Considering these aspects, more attention has been paid to the concept of corporate social responsibility 
in recent years, which refers to corporate policies and efforts made to protect and enhance both corporate benefits and social welfare $[9,10]$. Nowadays, more firms strive to reinforce ethical awareness and seek to promote public interests, and company managers assume that an individual's ethical sensitivity is the primary sources of motivation affecting the ethical behavior of workers [11,12]. Therefore, the influence of grades and academic background on university graduate employment is gradually decreasing, and it is meaningful step to change on recruitment system from specification-centered recruitment such as traditional educational background to personality-based [13-15]. Moreover, firms are applying various humanity evaluation models in personnel management, and universities are concentrating on applying the concept of sustainability as an effective method to achieve competitive advantage because competition among them is increasing as enrollment decreases due to a decrease in the number of students and rapid changes in the knowledge system $[16,17]$. Many universities currently provide ethics education and lectures on social responsibility to enhance the employability of students and help them become leaders who can contribute to social welfare through their university education [18].

While students obtain techniques and knowledge from a regular curriculum, such as the courses in their major fields and liberal arts classes, they also gain important experience in extracurricular activities such as clubs, hobbies, internship, and volunteering [19-21]. For example, they acquire a sense of responsibility, cooperation with other people, and empathy through such extracurricular activities. Danzberger and Blank [22] state that employers evaluate the basic qualifications of job seekers, such as individual characteristics, behaviors, and conformance to the firm's policies based on their experiences or performance when attending university because interpersonal abilities, attitudes toward tasks, overall behaviors, and a candidate's basic level of refinement, which are considered important in employment, are not recorded indicators. These abilities grow cumulatively through appropriate experiences and cannot be measured through the normal evaluation methods even though they are essential in every job. Nevertheless, they can be used as effective data for hiring appropriate candidates entering the labor market.

Education for sustainable development is reflected in various courses and activities at the universities. As environmental preservation, social justice, environmental justice, and economic justice are treated significantly in sustainability, education for human rights, diversity, and corporate responsibility can be integrated into a regular curriculum, education programs, and individual activities as part of regular courses. However, it is difficult to determine variables that can be used to analyze the performance of such education. Whereas the entry of qualified graduates into the labor market is one of the indicators reflecting the performance of universities, few studies have analyzed the effects both of curriculum-related variables, such as major fields and grades, and of education for sustainable development on the employment of university graduates due to a limited amount of data.

Confucian culture is a long-standing tradition permeating Korean society. It penetrates many aspects of the lives and culture of Koreans, thereby affecting them both consciously and unconsciously. Confucian culture has established family ties as the basis of moral norms and has made the ideal realization of personality as the goal of education and training. In modern society, it is essential to emphasize the development of human personality through the interaction of family ties with the larger community [23,24].

Sungkyunkwan University has been providing a unique humanities education based on benevolence for 619 years since its founding. It has developed and conducted diverse extracurricular programs to help students build character and has strived to enhance its liberal arts curriculum related to humanity. This study analyzes how the experience of participating in these extracurricular programs and activities to cultivate students' humanity beyond their major fields and grades impacts employment status based on the data of students who graduated from Sungkyunkwan University from 2008 to February 2015. It examines the effects of variables related to extracurricular activities, which are part of education for sustainable development, to evaluate the influence of such education on the entry of university graduates into the labor market. If students are not rewarded in the labor market for pursuing humanity education, universities cannot sustain offering such courses. Therefore, 
a virtuous circle that rewards students who have received humanity education in the labor market should be established.

This study is structured as follows. Sections 2 and 3 provides an introduction to Sungkyunkwan University and the higher education sector followed by the theoretical background and examination of previous studies. Section 4 will describe the methodology of this study, including the research objectives and data collection method. Section 5 discusses the findings and Section 6 concludes.

\section{Theoretical Background}

Korea has a significantly lower youth employment rate compared with Europe and other advanced countries, and even lower than the OECD (Organisation for Economic Co-operation and Development) average (see Figure 1). Only $27.2 \%$ of the population aged 15 to 24 are employed [25]. To solve the problems of youth unemployment and economic recession, firms are changing their standards for employment from hiring those who meet superficial conditions to hiring those who can cooperate, are eager to face challenges, and have humane qualities [26,27]. Firms have not been successful in selecting employees merely based on the information about grades, major fields, and certificates because retaining employees and achieving their adaptability to work situations has been difficult. In other words, although firms focus on expertize-based employment without considering human values during times of economic recession, they should maintain a balance between expertise and abilities to cope with such crises in the long term.

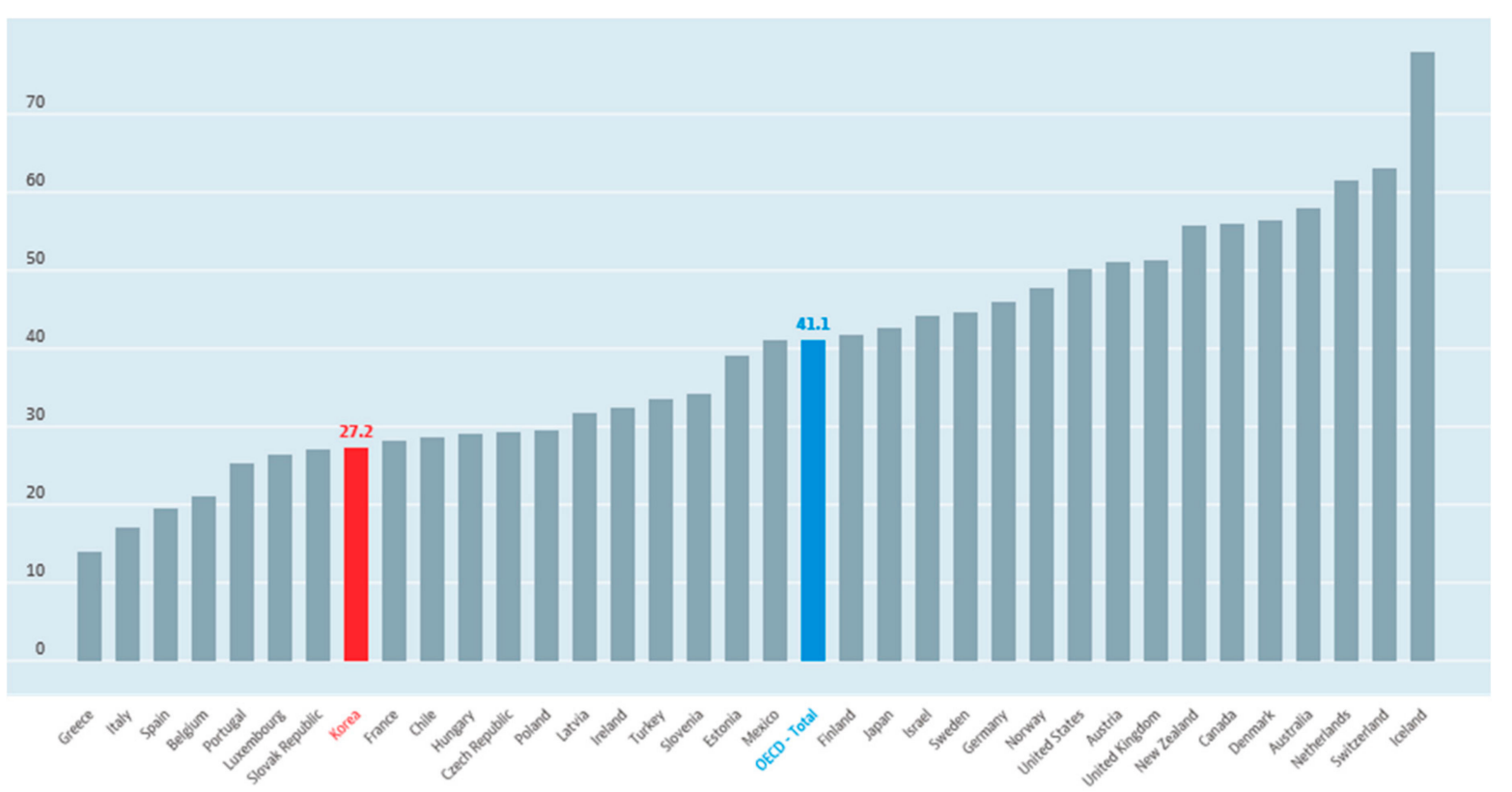

Figure 1. Employment/population ratio among the OECD countries. Source: [25]. Employment rate of 15-24-year-olds, \% in same age group (indicator).

While universities have long emphasized the basic competencies and thinking abilities of students, they have struggled to develop methods to improve individual attitudes and humanity [28]. Recently, it has been established that professional skills and techniques are necessary for entry into the labor market and individual characteristics are important for adaptation to rapidly changing environments and constant employment [29]. However, recruiters do not spend much time reviewing the applications of those seeking their first job after graduating from university [30] because job seekers tend to have similar numerical performance results, such as grades, when first entering the labor market, and thus they are selected through several stages of the application review process, such as interviews. Many studies have reported that individual humanity and basic capabilities serve as factors that can affect productivity in the labor market and can be acquired through experience and empirical 
knowledge [31]. Baek \& Cho [32] analyzed the effects of the personality variables reflected in the response patterns of student evaluations of teaching using the big five personality traits, and traits such as sincerity and cooperation can be screened by job interviews.

Figure 2 illustrates the standard of ideal talent for sustainable development pursued in Sungkyunkwan University, from which the target students in this study graduated. This standard is established to enable students to develop professional capabilities based on self-discipline, contribute to social advancement and prosperity of humankind, and serve as creative global leaders who are cultured, professional, and take the lead. Core competencies indicate the complex of knowledge, abilities, values, and attitudes that can be obtained by students who complete the university programs diligently, as well as the essential attributes for university graduates to achieve self-fulfillment and contribute to their community as mature members of society. Sungkyunkwan University was the first among Korean universities to implement regular course programs and extracurricular programs in 1996 to increase the competitiveness of its students and enable them to have both excellent work performance and humanity and meet its standard of ideal talent. These programs aim for fundamental refinement in students and have the specific objectives of enhancing their international mindset through foreign language learning and their passion for participating in social activities through volunteering.

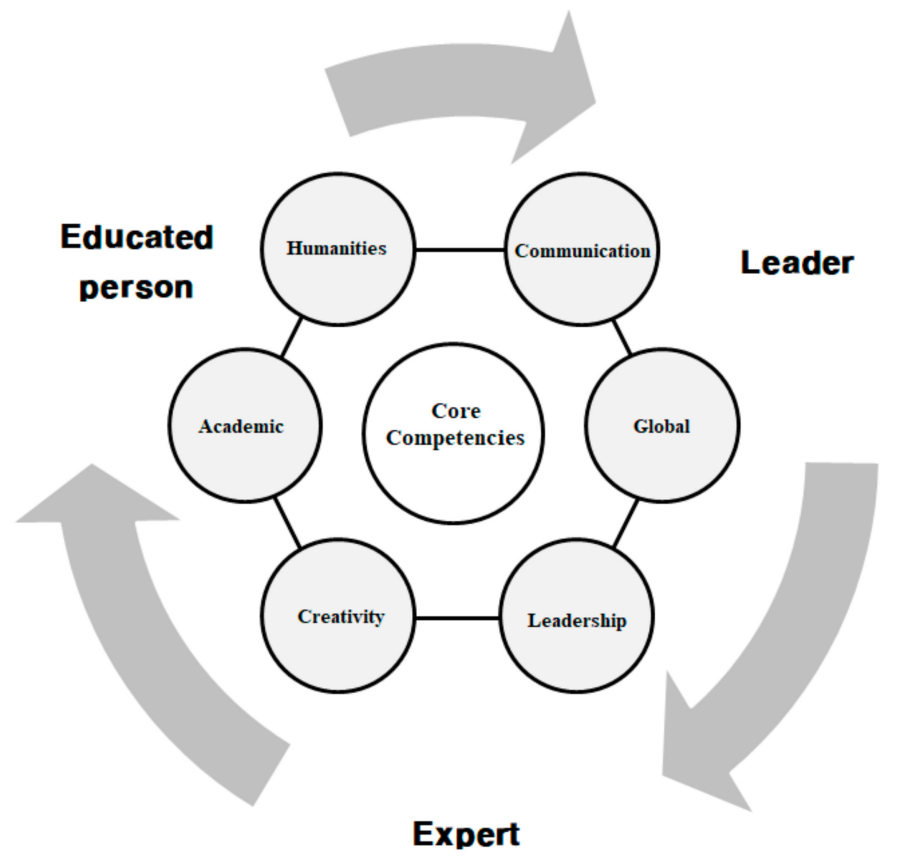

Figure 2. Standard of ideal talent and core competencies for sustainable development. Source: [33].

The Yorke \& Knight [34] working definition of employability defines such attributes as "a set of achievements, skills, understandings, and personal attributes that make graduates more likely to gain employment and be successful in their chosen occupations, which benefits themselves, the workforce, the community and the economy". Yorke [35] states that employability derives from the ways in which the student learns from his or her experiences. Recently, since universities put more focus on humanity education to produce the graduates with character as well as employability skills, it is increasingly important to examine the influence of humanity education programs through an empirical analysis, including volunteering activity on the graduate's transition to the job market. We analyze the effects of ideal talent and core competencies through humanity education on employability in this study and provide the empirical findings to improve the sustainability of the educational system. Moreover, students will have the opportunity to prepare for future employment through this virtuous circle. Thus, this study empirically analyzes a virtuous circle between humanity and employment by obtaining Education-Career matched data from Sungkyunkwan University, which is based on the principles of 
Confucianism. The courses that students took at university and their grades are considered as key features in college education, and feedback as employment outcomes increases the quality of courses as well as the probability of employment of university graduates [36-38]. In this study, the average grades at graduation, which reflect the general performance of university graduates in their major fields and courses, is controlled and the focus is on the effects of humanity education courses. Volunteer activities covered in the data of this study include volunteering at institutions offering public services and social welfare, international organizations, institutions suggested by the university, and in rural communities. These experiences are converted into intangible characteristics of individuals such as techniques, knowledge, humanity, creativity, interests, and capabilities and serve as a signal in the labor market. Valuable experiences such as overseas training and volunteering activities are regarded as a positive signal of individual attitudes and humanity such as leadership, teamwork, responsibility, and patience. In practice, it is known that human resource managers consider not only the grades and major fields of university graduates but also other factors, such as humanity and diverse experiences. Human capital and invisible characteristics formed through a regular curriculum and extracurricular activities are identified during interviews and aptitude tests for employment. Therefore, the results of the analysis of this study can contribute to establishing an education system for sustainable development and provide practical information to increase the probability of employment of talented students who take on social responsibilities.

\section{Literature Review}

Universities are promoting different methods to enhance graduate employability. These include embedding transferable skills and career development practices into the curriculum, such as communication skills, cooperative working, interpersonal sensitivity, reflection, and ethical understanding $[39,40]$ The existing literature related to the present study can be divided into two streams: first, the studies on the influence of the competence on job market performance; second, on the relation between humanity education such as volunteering activities and employability of the graduates.

The studies on the correlation between competence and job market performance indicate that not only the academic grades or performance in the educational and training programs which can be expressed in numbers or records, but also the competence, which can be improved through education, influence employment [32,41,42]. Heijke \& Ramaekers [43] stated that the development of knowledge and competence through education is an investment in human capital to enhance individual productivity and to generate profits in the labor market. In addition, García-Aracil \& Van der Velden [44] suggested that reaching a higher standard in competence leads to a higher job satisfaction of the graduates and subsequently, to greater productivity. Also, Nair et al. [45] investigated the difference between the competence acquired through education and the one required for the job in the study of Australian workers in engineering fields and revealed that social ethics as well as communication skills, leadership, ability to work with people having different backgrounds, are valued in corporations and the emphasis on such capabilities is not limited to engineering fields.

Universities also endorse students to pursue volunteering activities during their degree programs to optimize their employment opportunities as this can provide evidence to future employers about their social commitment and holistic university experience [46]. Encouraging the volunteering activities of students in higher education is regarded as a type of ethical participation. This helps students be responsible for others and gives them an opportunity to have an enhanced sense of responsibility and independence [46]. Also, the Department for Education and Skills [47] pointed out that volunteering is strongly correlated with students' employability and students are increasingly making a 'contribution to society'. In addition, the benefits of making the most of being at university in terms of future job opportunities are clearly recognized.

However, it is hard to find the studies which prove the correlation between employability and volunteering. While there are subjective data on how students feel, they have benefited from 
volunteering [48], and in many cases students do get jobs through volunteering (e.g., youth and conservation work), the absence of a control group means that the case for employability is not proven statistically. Some studies have indicated that participation in volunteering activities might have positive effects on employment. Hirst [49] conducted a survey of people who were registered at the Employment Service in the United Kingdom between 1999 and 2000 and found that approximately $88 \%$ of all job seekers and approximately $41 \%$ of current employees considered volunteering activities helpful for employment. Volunteering has positive effects for younger participants, or when it covers a duration of more than $50 \mathrm{~h}$, or is related to public institutions, cooperative movements, discussions, and examinations. These activities are also relevant to enhance interpersonal skills and humanity-based experience.

However, as there is a variety of factors influencing the graduate employability and students are involved in many other activities than volunteering, it is necessary to control other factors including academic grades and extracurricular activities which also have effects on employment. Due to the limited data, the existing studies were not able to completely consider these multiple factors but this study gives an empirical analysis of the influence of the volunteer activities and humanity-related curriculum subjects on employment while controlling other factors, including curricular and extracurricular activities, to assess pure effects of humanity education.

We were asking whether the social demand for education for sustainability development meets the demand for the labor market for graduates. Therefore, this study attempted to analyze the effect of the experience of participating in activities or education to cultivate students' humanity while controlling students' major fields, grades, or other extracurricular programs. If the positive elements of humanity education have a significant influence, then it will provide a very important point to prove that recruiters should not be dependent only on factors like grades. Also, it can be confirmed whether a virtuous circle that rewards students who have received humanity education in the labor market may be established.

\section{Methods}

\subsection{Data}

This study analyzes the effects of extracurricular activities at university on employment by obtaining Education-Career matched data, including data on grades of graduates of Sungkyunkwan University, extracurricular activities, employment statistics, and information on corporate sales announced by firms in the Data Analysis, Retrieval, and Transfer (DART) system operated by the Financial Supervisory Service [50]. This study was conducted on a total 15,180 employed or unemployed graduates from February 2008 to February 2015, but excluded those who advanced to graduate schools for higher degrees. Male students were 10,194, and female students were 4986 among the 15,180 students included in the analysis. Also, employed graduates were 12,477, and unemployed graduates were 2703. Students who went to graduates schools were 4760 and not included in the unemployed, and then they were excluded from the analysis. The data are used to consider grades, major fields, participation in training at international universities, grades for internationally authorized language tests, the status of prizes received in creativity-related contests, the status of certificates obtained on data processing, individual characteristics such as gender and age, the status of previous residence in the capital area, the status of graduation from an elite high school, and the status of entrance into an educational institution through special screening. In addition, the time spent in social volunteering activities and the status of completion of courses related to humanity are examined to identify their effects on employment.

The Education-Career matched data were obtained from the different divisions of Sungkyunkwan University and integrated; the data for grades and extracurricular activities of the graduates are collected by the Academic Affairs Division, and computerized and managed by the Information and Communications Division. The grade records of the graduates include information on all the courses 
he or she took in the university, thereby it is possible to identify the humanity-related curriculum courses that the graduates took during school days. On the other hand, extracurricular activities data show whether the graduates have studied in overseas or not, as well as the scores of the internationally authorized language tests and the status of certificates obtained on data processing. Employment statistics data, managed by the Student Affairs Division, include the employment status, the names of the employing companies, as well as personal information such as the student's major. An extensive amount of data were collected and merged under the student IDs to build a united Education-Career database; corporate financial data are also merged to consider more substantial variables related to employability.

The firm names indicated in the data of employment statistics can be referred back to the data of the Financial Supervisory Service to elicit corporate sales, net income, and annual mean wages and salaries. The information provided by firms becomes the basis for standards that many university graduates set to decide which firms they would like to work for [32]. In this study, corporate sales, which are used most frequently to measure the rank of firms, are applied as an index of quality.

Education and practice in etiquette is a humanity-related course that is not compulsory but is offered optionally at university. This course aims to help students learn the courtesy and manners required in modern society and how to conduct human relations to maintain a smooth social life. It is a general elective course in the Department of Confucian and Oriental Studies that can be taken regardless of department and year and consists of lectures on life etiquette, education in common courtesies, and practice focusing on traditional family rituals. In this course, students learn the theoretical background of manners and receive practical training in observing good manners in real life. In this regard, the goals of this course are to transfer theoretical knowledge and provide humanity education based on practical training. As humanity cannot be achieved through the accumulation of knowledge in the short term, it is formed through constant education that people have received since childhood. However, many university students are not accustomed to manners due to a lack of knowledge about them and limited experience of applying etiquette in real life, as shown in the use of slang and expletives or desisting from using titles. From this perspective, this course reflects humanity education based on various learning experiences and training in human decency, such as the establishment of a value system, tea ceremony, greetings, clothing, and table manners. In this course, students comprehend Korean culture and learn and practice basic common manners such as greetings and self-introductions, manners of social life, and manners about clothing. Specifically, they are informed about interpersonal relations, conversational skills, interview manners, and interview training, which can be of practical use in employment after graduation.

\subsection{Summary Statistics}

Table 1 indicates the means of variables related to humanity and performance shown in two groups according to the status of employment, and the t-test was performed to identify a statistically significant difference in various characteristics between the two groups. It is found that employed graduates participated in extracurricular activities on humanity more than the unemployed did. Specifically, approximately $19 \%$ of the university graduates who were employed and approximately $17 \%$ of those who were not employed took the course on courtesy education and practice related to humanity. Moreover, the university graduates who were employed took social volunteering activities for an average of approximately $62 \mathrm{~h}$. On the other hand, those who were not employed took these activities for approximately $55 \mathrm{~h}$, thus spending approximately seven hours less than the employed did. In addition, the employed showed better performance than the unemployed did in terms of extracurricular activities and grades. Approximately $3 \%$ of those who were employed and approximately $1 \%$ of those who were unemployed experienced studying abroad at international universities through a student exchange program. Unemployed graduates scored approximately 682 for internationally authorized language tests, lower than the employed graduates scored 708 on average. Students who talented in creativity were about $45 \%$ or 5615 of those who were employed and 
about $30 \%$ or 811 of those who were not employed. Total GPAs were higher for employed graduates; 3.53 on average in the employed group and 3.38 in the unemployed group.

The average age of the unemployed was 26.4, with slightly higher than those who were employed of 26.0. Female students were approximately $30 \%$ or 3743 of those who were employed and approximately $46 \%$ or 1243 of those who were not employed. Approximately $69 \%$ of those who were employed and approximately $71 \%$ of those who were not employed were from capital areas including Seoul and metropolitan. Students who graduated from an elite high school were about 7\% or 873 of the employed group and about $4 \%$ or 108 of the unemployed group. The ratio of employed graduates with special admission was about $17 \%$ or 2121 , higher than those of unemployed graduates about $14 \%$ or 378 .

Table 1. Summary statistics.

\begin{tabular}{|c|c|c|c|c|}
\hline & \multirow{2}{*}{$\begin{array}{c}\text { Employed } \\
\text { Mean }\end{array}$} & \multirow{2}{*}{$\begin{array}{c}\text { Unemployed } \\
\text { Mean }\end{array}$} & \multicolumn{2}{|c|}{ Significance of Difference } \\
\hline & & & Difference & $p$-Value \\
\hline \multicolumn{5}{|l|}{ Humanity } \\
\hline $\begin{array}{c}\text { Completion of courtesy education and } \\
\text { practice course }\end{array}$ & $0.19(0.39)$ & $0.17(0.38)$ & $0.016^{* *}$ & $(0.042)$ \\
\hline Time spent for social volunteer activities & $62.32(62.60)$ & $54.64(55.08)$ & $7.680 * * *$ & $(0.000)$ \\
\hline \multicolumn{5}{|l|}{ Extracurricular activities } \\
\hline $\begin{array}{c}\text { Studying abroad at international } \\
\text { universities }\end{array}$ & $0.03(0.16)$ & $0.01(0.10)$ & $0.017^{* * *}$ & $(0.000)$ \\
\hline $\begin{array}{c}\text { Grades on internationally authorized } \\
\text { language tests }\end{array}$ & $\begin{array}{c}707.74 \\
(103.17)\end{array}$ & $\begin{array}{c}682.44 \\
(131.34)\end{array}$ & $25.298^{* * *}$ & $(0.000)$ \\
\hline $\begin{array}{l}\text { Awarded in creativity-related contests or } \\
\text { applied for patents }\end{array}$ & $0.45(0.50)$ & $0.30(0.46)$ & $0.148^{* * *}$ & $(0.000)$ \\
\hline \multicolumn{5}{|l|}{ Graduates' performance } \\
\hline Total GPA & $3.53(0.37)$ & $3.38(0.44)$ & $0.140 * * *$ & $(0.000)$ \\
\hline \multicolumn{5}{|l|}{ Graduates' characteristics } \\
\hline Age & $26.01(2.16)$ & $26.35(2.71)$ & $-0.345^{* * *}$ & $(0.000)$ \\
\hline Female student & $0.30(0.46)$ & $0.46(0.50)$ & $-0.158^{* * *}$ & $(0.000)$ \\
\hline Capital areas & $0.69(0.46)$ & $0.71(0.46)$ & $-0.018 *$ & $(0.057)$ \\
\hline Elite high school graduation & $0.07(0.25)$ & $0.04(0.20)$ & $0.025^{* * *}$ & $(0.000)$ \\
\hline Special admission & $0.17(0.38)$ & $0.14(0.35)$ & $0.027^{* * *}$ & $(0.000)$ \\
\hline Observations & 12,477 & 2703 & & \\
\hline
\end{tabular}

\subsection{Empirical Framework}

In this study, the status of employment was set as a dependent variable to estimate a binary logit model. Model 1 includes independent variables on the experience of performing humanity-related activities. In the section on humanity, a dummy variable for the completion of courtesy education and practice course and a continuous variable of the time spent in social volunteer activities are included. Specific elements for extracurricular activities are considered in Model 2. In the section on international affairs, the experience of studying abroad at international universities through a student exchange program is considered in addition to the continuous variable of grades on authorized language tests converted to the equivalent grades on the TOEIC (Test of English for International Communication). In the section on creativity, students who received a prize in the third or higher class from national creativity-related contests, and students who have applied for a patent are considered to examine the employment outcomes of such achievements. In Model 3, the mean of grades is applied to Model 2 for analysis. The effects of various extracurricular activities might reflect the characteristics of groups that participated in them. For example, the student exchange program requires a low mean 
of grades of 2.0 or higher, which is a selection criterion. However, if only students who have excellent grades apply to and participate in this program due to selective acceptance, the positive effects of this program on employment might be affected by the characteristics of students who have excellent grades. For this reason, variables for individual characteristics and background are also included in Model 4. Among the variables on individual characteristics and background, indexes that indicate the performance of university graduates before they enrolled in the university are considered, such as dummy variables for gender, age, the status of previous residence in the capital areas including Seoul and Gyeonggi-do, the status of graduation from an elite high school, and the status of enrollment in the university as an academically talented student or a student with a special talent. While existing studies have encountered the problem of significant differences among those who graduated from certain universities, this study does not encounter this problem as it targets students who graduated from the same university. Furthermore, the year of graduation and major field are set as explanatory variables to control for differences according to the year and major field.

Subsequently, the multinomial logit model is applied to divide firms into ten conglomerates, the top $25 \%$ to $50 \%$ firms, top $25 \%$ to $75 \%$ firms, and top $75 \%$ or lower firms based on corporate sales and to analyze the effects of extracurricular activities on the reputations or quality of employment of the firms that university graduates work for. In this study, employment performance is measured based on the status of employment and the sales, net income, and annual mean of wages and salaries of the firm a university graduate works for. To overcome the limitations of the data used in this study due to employment statistics that lack the wages or salary of a university graduate, these were related to the data announced by firms in the DART system operated by the Financial Supervisory Service for measuring the quality of employment or reputation of the firm a university graduate works for based on corporate sales, net income, and annual mean of wages and salaries. These indexes might be incomplete measures of the value of education because the goal of university education is not to focus only on employment outcomes. Nevertheless, variables on the status and outcomes of employment can be effectively applied because they can be obtained in the data used in this study and serve as a positive signal that indicates the human capital, such as the amount of knowledge and techniques, that a university graduate has accumulated. The multinomial logit model targets the unemployed and those employed in corporations from official data of the Financial Supervisory Service. The regression equation for the multinomial logit model is as follows.

$$
P\left(y_{i}\right)=\prod_{j=1}^{J-1} \frac{\exp \left(\beta_{i j} x_{j}\right)}{\sum_{l=j}^{J} \exp \left(\beta_{i l} x_{l}\right)}, j=0,1,2,3,4 .
$$

This indicates the probability that university graduate $i$ is employed in a firm corresponding to each category compared to the standard category, which is the unemployed.

\section{Results}

Table 2 shows the results of analyzing the binary logit model, where a status of employment is set as a dependent variable. Model 1 was analyzed to examine the effects of indexes related to humanity on employment. The results of the analysis verify that university graduates who completed the course of etiquette education and practice show a probability of employment approximately $3.7 \%$ higher than those who did not complete it. Moreover, an increase by one unit in the amount of time spent on social volunteering activities increases the probability of employment by approximately $0.2 \%$. The results of applying extracurricular activities, which imply international and creative experiences, in Model 2 confirm that studying abroad at international universities and higher grades on internationally authorized language tests, which are converted to the grades for the TOEIC, has positive effects on employment. Moreover, the status of prizes received from creativity-related contests and of patents applied for can affect employment positively. 
The results of analyzing Model 3 by applying the mean of grades to Model 2 show that the coefficient values of variables related to the completion of courtesy education and practice course, social volunteer activities, and extracurricular activities are statistically significant despite a slight decrease in these values. Model 4 was examined by applying the variable of age and dummy variables such as the status of being a female student, the status of previous residence in the capital areas, the status of graduation from an elite high school, and the status of enrollment into an educational institute as a talented student to Model 3. These results indicate that the completion of courtesy education and practice course has significantly positive effects on employment despite a slight decrease in its coefficient value, and that participation in extracurricular activities and the mean of grades also affect employment. The graduates' background had a significant effect on employment. Graduating from an elite high school had a positive impact on employment; in addition, people who were admitted to college via special admission were more likely to be hired. Age had a negative effect on employment overall, but gender (i.e., being female) had a negative impact on employment.

Table 2. Logit estimates of employment.

\begin{tabular}{|c|c|c|c|c|}
\hline & Model 1 & Model 2 & Model 3 & Model 4 \\
\hline Completion of courtesy education and practice course & $\begin{array}{c}0.037 * * \\
(0.013)\end{array}$ & $\begin{array}{c}0.027 * * \\
(0.013)\end{array}$ & $\begin{array}{c}0.025 * * \\
(0.013)\end{array}$ & $\begin{array}{c}0.024 * * \\
(0.013)\end{array}$ \\
\hline Amount of time for social volunteering activities/10 & $\begin{array}{c}0.002 * * * \\
(0.001)\end{array}$ & $\begin{array}{c}0.001 * * \\
(0.001)\end{array}$ & $\begin{array}{l}0.001 * \\
(0.001)\end{array}$ & $\begin{array}{l}0.001 * \\
(0.001)\end{array}$ \\
\hline Experience studying abroad & & $\begin{array}{c}0.090 * * * \\
(0.027)\end{array}$ & $\begin{array}{c}0.086^{* * *} \\
(0.026)\end{array}$ & $\begin{array}{c}0.082 * * * \\
(0.026)\end{array}$ \\
\hline Grades for internationally authorized language tests $/ 10$ & & $\begin{array}{c}0.002 * * * \\
(0.000)\end{array}$ & $\begin{array}{c}0.002 * * * \\
(0.000)\end{array}$ & $\begin{array}{c}0.002 \text { *** } \\
(0.000)\end{array}$ \\
\hline Student talented in creativity & & $\begin{array}{c}0.042 \text { *** } \\
(0.006)\end{array}$ & $\begin{array}{c}0.034^{* * *} \\
(0.006)\end{array}$ & $\begin{array}{c}0.032 * * * \\
(0.006)\end{array}$ \\
\hline Mean of grades & & & $\begin{array}{c}0.079 * * * \\
(0.008)\end{array}$ & $\begin{array}{c}0.084^{* * *} \\
(0.008)\end{array}$ \\
\hline Age & & & & $\begin{array}{c}-0.012 * * * \\
(0.002)\end{array}$ \\
\hline Female student & & & & $\begin{array}{c}-0.114^{* * *} \\
(0.007)\end{array}$ \\
\hline Capital areas & & & & $\begin{array}{c}0.023^{* * *} \\
(0.006)\end{array}$ \\
\hline Elite high school graduation & & & & $\begin{array}{c}0.034^{* *} \\
(0.014)\end{array}$ \\
\hline Special admission & & & & $\begin{array}{c}0.021 * * \\
(0.008)\end{array}$ \\
\hline Year of graduation & Yes & Yes & Yes & Yes \\
\hline Major field & Yes & Yes & Yes & Yes \\
\hline Observations & \multicolumn{4}{|c|}{15,180} \\
\hline
\end{tabular}

Notes: 1. Robust standard errors are shown in parentheses; 2 . The coefficient value refers to the marginal effect estimates; $3{ }^{* * *} p<0.01,{ }^{* *} p<0.05,{ }^{*} p<0.1$.

Table 3 displays the results of analyzing the effects of humanity-related activities and other extracurricular activities on the quality of employment or corporate reputation in the multinomial logit model, where groups are classified based on sales. The unemployed are the standard category. The results of this analysis verify that the completion of the courtesy education and practice course, which is an extracurricular activity related to humanity, does not affect the quality of employment and that university graduates who participated in social volunteering activities have a higher probability of employment in the middle and upper-level firms than those who did not. Studying at an international 
university does not have significant effects on employment in the groups of middle and low-level firms. On the other hand, university graduates who have this experience are more likely to be employed in upper or low-level firms than the unemployed who do not. University graduates with higher grades on internationally authorized language tests, high means of grades, or who were selected as talented students for creativity show a higher probability of employment than those who do not. Specifically, university graduates who have high means of grades tend to be employed in so-called excellent firms.

Table 3. Multinomial logit estimates of employment prestige.

\begin{tabular}{ccccc}
\hline & Top 10 Firms & Upper-Middle & Middle-Low & Low-Rank \\
\hline \multirow{2}{*}{ Courtesy education and practice course } & 0.084 & 0.043 & -0.026 & 0.024 \\
& $(0.079)$ & $(0.078)$ & $(0.150)$ & $(0.068)$ \\
\hline \multirow{2}{*}{ Time for volunteering activities/10 } & $0.011^{*}$ & $0.011^{* *}$ & 0.010 & 0.005 \\
& $(0.006)$ & $(0.005)$ & $(0.010)$ & $(0.005)$ \\
\hline Experience in studying abroad & $0.891^{* * *}$ & $0.880^{* * *}$ & 0.477 & $0.514^{* *}$ \\
& $(0.229)$ & $(0.232)$ & $(0.466)$ & $(0.225)$ \\
\hline Grades for language test/10 & $0.024^{* * *}$ & $0.018^{* * *}$ & $0.024^{* * *}$ & $0.008^{* * *}$ \\
& $(0.002)$ & $(0.002)$ & $(0.005)$ & $(0.002)$ \\
\hline Student talented in creativity & $0.369^{* * *}$ & $0.425^{* * *}$ & $0.324^{* *}$ & $0.109^{* *}$ \\
& $(0.064)$ & $(0.063)$ & $(0.120)$ & $(0.056)$ \\
\hline Mean of grades & $1.264^{* * *}$ & $0.691 * * *$ & $0.601 * * *$ & $0.487^{* * *}$ \\
Year of graduation & $(0.092)$ & $(0.088)$ & $(0.178)$ & $(0.072)$ \\
\hline Major field & \multicolumn{3}{c}{ Yes } \\
\hline Observations & \multicolumn{2}{c}{14,084} & \\
\hline
\end{tabular}

Notes: 1. Student's age, student's gender (female $=1$ ), dummy variables of Seoul, metropolitan, and local (reference group of region is local city), high school graduation (elite high school =1), admission type (special = 1), major, and graduation year are included in the analysis but not reported; 2 . Robust standard errors are shown in parentheses; 3 . The coefficient value refers to the odds ratio estimates; $4 .{ }^{* * *} p<0.01,{ }^{* *} p<0.05,{ }^{*} p<0.1$.

Although major firms are changing their standards for recruitment to emphasize humanity beyond hiring practices based on qualifications or academic achievement, the results of the analysis in this study indicate that the effects of humanity-related indexes are insignificant. On the other hand, a high grade and the experience of studying abroad increased the probability of being employed by large corporations and companies with higher sales. Further, tangible facts like grades on internationally authorized language tests or acquisition of certificates affect the quality of employment, including the status of getting hired by major firms, as shown in the results of previous studies. This result implies that recruiters still prefer such elements as major fields and academic performance over hidden aspects of individual humanity, and a mechanism for identifying invisible characteristics is not working properly.

\section{Discussion and Conclusions}

While education is considered an individual investment in neoliberal economics, it is also regarded as a fundamental right in establishing a society guaranteeing human rights [51]. Education aims at supporting human growth and equality, promoting human rights, and widening the perspectives of the student. As education is related to the way of life in a community, cooperative skills, and adding creative value to firms beyond individual investment, it should strive to enhance both personal capabilities and competencies in achieving coexistence and shared prosperity. A virtuous circle between education and the labor market should be ensured to maintain the sustainability of humanity education. This study analyzed such a virtuous circle, which varies by country, at a Confucian university in South Korea, one of the Asian countries dominated by Confucianism. 
Humanity and sociality enhancement education to encourage sustainable development and a sense of community and morality is expected to increase in importance, unlike expertise that can be replaced by technological innovations such as artificial intelligence. The trends of employment in the labor market are also changing. For example, public organizations are implementing a blind interview system that promotes fairer evaluation by removing personal information that can cause distortions due to prejudice in place of the current unstructured interview system that includes questions irrelevant to work, such as academic background. Firms are also applying national competency standards that facilitate evaluation based on work performance, humanity, and creativity. This study provides empirical evidence using graduates' Education-Career matched data for existing theoretical research which have reported that individual humanity serves as a factor that can affect productivity in the labor market [31,47]. The results of the empirical analysis in this study verify that factors such as ethics education, including courtesy education and practice and social volunteering activities, have positive effects on employment. Also, the results support the idea that social ethics are valued in corporations [45], and humanity education or ethical participation enables students to improve their employability through qualities such as sense of responsibility and independence [46]. This indicates that an increasing number of firms are focusing on the importance of humanity and are willing to hire job seekers with ethical understanding. However, these factors either do not have or have insignificant effects on the probability of employment in four groups of companies defined by sales, which indicates the quality of employment. It implies that during recruitment, major firms still hire university graduates based on factual information such as grades and the acquisition of certificates instead of invisible characteristics such as humanity in interviews even though they have been criticized for the deficiencies of this current recruitment system [14].

This study shows that humanity education influences on employment through variables of courtesy education and practice and social volunteering activities, although measurability of this element is still a limitation. Nevertheless, this study empirically confirmed the existence of the effects of humanity education in the transition to labor market of college graduates even after controlling for academic performance and extracurricular activities, compared to some studies which investigate the relations between humanity education and employability of the graduates using a survey or subjective data due to a limited amount of data [48,49]. This suggests that the university can provide a framework for discussion on sustainability education in line with the labor market demand. Results of the analysis in this study are significant in verifying that the minimum level of refinement of university students and promotion of their participation in social volunteering can have positive effects on employment. These effects enable them to serve as responsible citizens, workers, managers, and government officials in society and their communities, thereby leading to the sustainability of a virtuous circle between education and social and economic activities.

To realize this virtuous circle, a university education system and recruitment environment that link humanity education to labor market outcomes should be created. Firms should establish a specific employment manual to identify the invisible characteristics in job seekers that help them function as responsible citizens, workers, managers, and government officials, and facilitate the sustainability of a virtuous circle between education and social and economic activities. Moreover, universities should formulate an integrated educational system combining major-field expertise, human growth, equality, and human rights to enhance the virtuous circle. As universities provide programs on education for sustainable development, an appropriate evaluation system for the outcomes of capability enhancement through these programs should be established.

Author Contributions: Joonmo Cho designed the research; Wonyoung Baek analyzed the data. Both authors wrote the paper, read, and approved the final manuscript.

Conflicts of Interest: The authors declare no conflict of interest. 


\section{References}

1. Leal Filho, W. Dealing with misconceptions on the concept of sustainability. Int. J. Sustain. High. Educ. 2000, 1, 9-19. [CrossRef]

2. Bessant, S.E.; Robinson, Z.P.; Ormerod, R.M. Neoliberalism, new public management and the sustainable development agenda of higher education: History, contradictions and synergies. Environ. Educ. Res. 2015, 21, 417-432. [CrossRef]

3. Wright, T.S. Definitions and frameworks for environmental sustainability in higher education. High. Educ. Policy 2002, 15, 105-120. [CrossRef]

4. Van Weenen, H. Towards a vision of a sustainable university. Int. J. Sustain. High. Educ. 2000, 1, $20-34$. [CrossRef]

5. Corcoran, P.B.; Wals, A.E. Higher Education and the Challenge of Sustainability: Problematics, Promise and Practice; Kluwer Academic Press: Dordrecht, The Netherlands, 2004; pp. 7-19.

6. Gough, S.; Scott, W. Higher Education and Sustainable Development: Paradox and Possibility; Routledge: London, UK, 2008.

7. Son, S.-N. A didactical reflection on character education in university. Korean J. Gen. Educ. 2016, 8, 11-41.

8. Min, C.-G. Direction of global programs for enhancing students' character and citizenship. Korean J. Gen. Educ. 2016, 10, 447-486.

9. Keith, D.; Blomstrom, R.L. Business and Society: Environment and Responsibility; McGraw Hill: New York, NY, USA, 1975.

10. Matten, D.; Moon, J. “Implicit” and "explicit" CSR: A conceptual framework for a comparative understanding of corporate social responsibility. Acad. Manag. Rev. 2008, 33, 404-424. [CrossRef]

11. Metzger, M.; Dalton, D.R.; Hill, J.W. The organization of ethics and the ethics of organizations: The case for expanded organizational ethics audits. Bus. Ethics Q. 1993, 3, 27-43. [CrossRef]

12. James, H.S. Reinforcing ethical decision making through organizational structure. J. Bus. Ethics 2000, 28, 43-58. [CrossRef]

13. Schomburg, H.; Teichler, U. Higher Education and Graduate Employment in Europe: Results from Graduates Surveys from Twelve Countries; Springer Science \& Business Media: Dordrecht, The Netherlands, 2007.

14. Cappelli, P. Why Good People Can't Get Jobs: The Skills Gap and What Firms Can Do about It; Wharton Digital Press: Philadelphia, PA, USA, 2012.

15. Lee, J.-C.; Park, J.-H. Theoretical approach to university students employment and the applicability search on NCS based recruitment. Korean J. Employ. Career 2015, 12, 139-160.

16. Baker, M.J.; Balmer, J.M. Visual identity: Trappings or substance? Eur. J. Mark. 1997, 31, 366-382. [CrossRef]

17. Melewar, T.; Akel, S. The role of corporate identity in the higher education sector: A case study. Corp. Commun. Int. J. 2005, 10, 41-57. [CrossRef]

18. Angelidis, J.P.; Ibrahim, N.A. Practical implications of educational background on future corporate executives' social responsibility orientation. Teach. Bus. Ethics 2002, 6, 117-126. [CrossRef]

19. Gault, J.; Redington, J.; Schlager, T. Undergraduate business internships and career success: Are they related? J. Mark. Educ. 2000, 22, 45-53. [CrossRef]

20. Wolbers, M.H. Job Mismatches and their Labour-Market Effects among School-Leavers in Europe. Eur. Sociol. Rev. 2003, 19, 249-266. [CrossRef]

21. Moynihan, L.M.; Roehling, M.V.; LePine, M.A.; Boswell, W.R. A longitudinal study of the relationships among job search self-efficacy, job interviews, and employment outcomes. J. Bus. Psychol. 2003, 18, 207-233. [CrossRef]

22. Danzberger, J.P.; Blank, M.J. Accredited Training for Work; National Conference of State Legislatures: Washington, DC, USA, 1985.

23. Kim, A.E.; Park, G.S. Nationalism, Confucianism, work ethic and industrialization in South Korea. J. Contemp. Asia 2003, 33, 37-49. [CrossRef]

24. Park, H.; Rehg, M.T.; Lee, D. The influence of Confucian ethics and collectivism on whistleblowing intentions: A study of South Korean public employees. J. Bus. Ethics 2005, 58, 387-403. [CrossRef]

25. Organisation for Economic Co-Operation and Development (OECD). Employment Rate by Age Group (Indicator); OECD: Paris, France, 2017. [CrossRef] 
26. Kanter, R.M. Challenge of Organizational Change: How Companies Experience It and Leaders Guide It; Simon and Schuster: New York, NY, USA, 2003.

27. Gardner, H.E.; Csikszentmihalyi, M.; Damon, W. Good Work: When Excellence and Ethics Meet; Basic Books: New York, NY, USA, 2008.

28. Hill, R.B.; Petty, G.C. A new look at selected employability skills: A factor analysis of the occupational work ethic. J. Vocat. Educ. Res. 1995, 20, 59-73.

29. Fugate, M.; Kinicki, A.J.; Ashforth, B.E. Employability: A psycho-social construct, its dimensions, and applications. J. Vocat. Behav. 2004, 65, 14-38. [CrossRef]

30. Lahey, J.N.; Beasley, R.A. Computerizing audit studies. J. Econ. Behav. Organ. 2009, 70, 508-514. [CrossRef] [PubMed]

31. Hills, J.; Robertson, G.; Walker, R.; Adey, M.; Nixon, I. Bridging the gap between degree programme curricula and employability through implementation of work-related learning. Teach. High. Educ. 2003, 8, 211-231. [CrossRef]

32. Baek, W.; Cho, J. Challenging the sustainability of an education system of evaluation and labor market outcomes. Sustainability 2015, 7, 16060-16075. [CrossRef]

33. Sungkyunkwan University. 4th Year Business Plan of Advancement of College Education; Administration of Sungkyunkwan University: Seoul, Korea, 2013.

34. Yorke, M.; Knight, P. Embedding Employability into the Curriculum; Higher Education Academy: York, UK, 2006.

35. Yorke, M. Employability in Higher Education: What It Is-What It Is Not; Higher Education Academy: York, UK, 2006.

36. Lee, J.; Cho, J. Who teaches economics courses better? Using student-professor matched data for the principle of economics course. Appl. Econ. Lett. 2014, 21, 934-937. [CrossRef]

37. Cho, D.; Baek, W.; Cho, J. Why do good performing students highly rate their instructors? Evidence from a natural experiment. Econ. Educ. Rev. 2015, 49, 172-179. [CrossRef]

38. Cho, D.; Cho, J. Does More Accurate Knowledge of Course Grades Impact Teaching Evaluation? Educ. Financ. Policy 2017, 12, 224-240. [CrossRef]

39. McMurray, I.; Roberts, P.; Robertson, I.; Teoh, K. An Action Research Project Exploring the Psychology Curriculum and Transitions to Employment. Psychol. Teach. Rev. 2011, 17, 50-63.

40. Robertson, S.I.; McMurray, I.; Roberts, P. Finding the employability edge in your studies. Psychologist 2012, 25, 710-713.

41. Lassibille, G.; Gómez, L.N.; Ramos, I.A.; de la O Sánchez, C. Youth transition from school to work in Spain. Econ. Edu. Rev. 2001, 20, 139-149. [CrossRef]

42. Arcidiacono, P. Ability sorting and the returns to college major. J. Econom. 2004, 121, 343-375. [CrossRef]

43. Heijke, H.; Ramaekers, G. The knowledge and skills of economics graduates and their significance on the labour market. In Key Qualifications in Work and Education; Springer: Dordrecht, The Netherlands, 1998; pp. 221-244.

44. García-Aracil, A.; Van der Velden, R. Competencies for young European higher education graduates: Labor market mismatches and their payoffs. High. Educ. 2008, 55, 219-239. [CrossRef]

45. Nair, C.S.; Patil, A.; Mertova, P. Re-engineering graduate skills-A case study. Eur. J. Eng. Educ. 2009, 34, 131-139. [CrossRef]

46. Holdsworth, C.; Quinn, J. Student volunteering in English higher education. Stud. High. Educ. 2010, 35, 113-127. [CrossRef]

47. Department for Education and Skills. The Future of Higher Education; Department for Education and Skills: London, UK, 2003.

48. Burke, S. Exploration of the Impact of Volunteering Opportunities Coordinated by the University of Liverpool; University of Liverpool Active Community Fund: Liverpool, UK, 2006.

49. Hirst, A. Links between Volunteering and Employability; Department for Education and Skills: London, UK, 2001.

50. Corporate Information Database (2008-2015). Available online: http:/ / dart.fss.or.kr (accessed on 15 May 2017).

51. Hausstätter, R.S.; Takala, M. The core of special teacher education: A comparison of Finland and Norway. Eur. J. Spec. Needs Educ. 2008, 23, 121-134. [CrossRef]

(C) 2018 by the authors. Licensee MDPI, Basel, Switzerland. This article is an open access article distributed under the terms and conditions of the Creative Commons Attribution (CC BY) license (http://creativecommons.org/licenses/by/4.0/). 